\title{
A new karyotype for Rhipidomys (Rodentia, Cricetidae) from Southeastern Brazil
}

\author{
Ana Heloisa de Carvalho', Maria Olímpia Garcia Lopes², Marta Svartman' \\ I Universidade Federal de Minas Gerais, Laboratório de Citogenética Evolutiva, Departamento de Biologia \\ Geral, Instituto de Ciências Biológicas, Av. Antônio Carlos, 6627 - Pampulha, 31270-910, Belo Horizonte, \\ Brazil 2 Biodiversity Salvation, Rua Joäo Pinheiro, 282, Centro, 37925-000, Piumbi, Minas Gerais, Brazil \\ Corresponding author: Marta Svartman (svartmanm@icb.ufmg.br)
}

Academic editor: Jan Zima | Received 24 November 2011 | Accepted 18 June 2012 | Published 9 July 2012

Citation: de Carvalho AH, Lopes MOG, Svartman M (2012) A new karyotype for Rhipidomys (Rodentia, Cricetidae) from Southeastern Brazil. Comparative Cytogenetics 6(3): 227-237. doi: 10.3897/CompCytogen.v6i3.2432

\begin{abstract}
In this work we present a new karyotype for Rhipidomys Tschudi, 1845 (Cricetidae, Rodentia) from Brazil. Our chromosome analyses included GTG- and CBG-banding patterns, the localization of the nucleolus organizer regions after silver staining (Ag-NORs) and fluorescence in situ hybridization (FISH) with a telomere probe. The new karyotype is composed of 44 chromosomes and has a fundamental number (number of autosomal arms) of 48. Most Rhipidomys species already karyotyped presented similar complements with $2 n=44$, but their fundamental numbers varied from $F N=46$ to 80 , a variation that has been mainly attributed to pericentric inversions. The comparison of this new karyotype to those of other Rhipidomys already reported allowed us to conclude that it is a distinctive chromosome complement, which can be of great use as a tool for the very complicated taxonomic identification in this genus.
\end{abstract}

\section{Keywords}

Rhipidomys, chromosome banding, FISH

\section{Introduction}

The Neotropical rodent Rhipidomys Tschudi, 1845 (family Cricetidae) is an arboreal genus belonging to the largely diverse subfamily Sigmodontinae, whose phylogenetic relationships are difficult to resolve, resulting in taxonomic uncertainties at every level, from species to tribes (Musser and Carleton 2005).

Copyright Ana Heloisa de Carvalho et al. This is an open access article distributed under the terms of the Creative Commons Attribution License 3.0 (CC-BY), which permits unrestricted use, distribution, and reproduction in any medium, provided the original author and source are credited. 
Rhipidomys is widely distributed and has been reported from Panama to southeastern Brazil and northern Argentina. The distribution of many species remains uncertain and there are several reports of undescribed species (Tribe 1996, Musser and Carleton 2005). Besides the eighteen species recognized by Musser and Carleton (2005), three additional species have been identified: $R$. ipukensis Rocha et al., 2011, $R$. tribei Costa et al., 2011 and $R$. itoan Costa et al., 2011, and a further unnamed clade from central and eastern Brazil has been recognized (Costa et al. 2011, Rocha et al. 2011). Twelve of the recognized Rhipidomys species have been found in Brazil: $R$. macconnelli De Winton, 1900, R. leucodactylus Tschudi, 1845, R. wetzeli Gardner, 1989, R. nitela Thomas, 1901, R. macrurus Gervais, 1855, R. gardneri Patton et al., 2000, R. emiliae J.A. Allen, 1916, $R$. mastacalis Lund, 1840, $R$. cariri Tribe, 2005, $R$. ipukensis, $R$. tribei and $R$. itoan, and an additional undescribed species has been reported as Rhipidomys sp 2 (Tribe 1996, Musser and Carleton 2005, Bonvicino et al. 2008, Costa et al. 2011).

Eleven species of Rhipidomys have already been karyotyped and, with the exception of $R$. nitela $(2 \mathrm{n}=48)$ and Rhipidomys prope nitela $(2 \mathrm{n}=50)$, all presented karyotypes with $2 \mathrm{n}=44$ chromosomes. In contrast with the conservation of diploid numbers, the karyotypes of Rhipidomys showed fundamental numbers ranging from $\mathrm{FN}=46$ to 80, a variation mainly attributed to pericentric inversions. The available karyotypical data for Rhipidomys are summarized in Table 1. Most cytogenetic studies on this genus were performed with conventionally stained karyotypes and in less than half the GTGCBG- or AgNOR-banding patterns were also included.

Table 1. Summary of the available chromosome data for Rhipidomys. ${ }^{1}$ As $R$. sclateri, which was later considered a synonym of $R$. leucodactylus (Musser and Carleton 2005). ${ }^{2}$ Identified by Tribe (1996), originally reported as Rhipidomys sp. ${ }^{3}$ As $R$. cearanus (Zanchin et al. 1992), later considered as a synonym of $R$. mastacalis (Musser and Carleton 2005).

\begin{tabular}{|c|c|c|c|c|}
\hline Group & Species & $2 n / F N$ & Locality & Reference \\
\hline \multirow{14}{*}{$\begin{array}{l}\text { Rhipidomys } \\
\text { leucodactylus }\end{array}$} & \multirow{4}{*}{ R. leucodactylus } & $44 / 46$ & Rio Juruá (AM) & Patton et al. 2000 \\
\hline & & $44 / 48$ & $\begin{array}{l}\text { Rio Jamari (RO), Caldas Novas, } \\
\text { Serra da Mesa (GO) }\end{array}$ & $\begin{array}{l}\text { Zanchin et al. 1992, } \\
\text { Andrades-Miranda et al. } 2002\end{array}$ \\
\hline & & $44 / 48^{1}$ & Cueva del Agua (Venezuela) & Aguilera et al. 1994 \\
\hline & & $44 / 52$ & $\begin{array}{l}\text { Serra da Mesa (GO), } \\
\text { Caxiuanã (PA) }\end{array}$ & Andrades-Miranda et al. 2002 \\
\hline & Rhipidomus sp. & $44 / 48$ & Berilo (MG) & This work \\
\hline & R. latimanus & $44 / 48$ & Peńas Blancas (Colômbia) & Gardner and Patton 1976 \\
\hline & \multirow[t]{2}{*}{ R. macrurus } & $44 / 48$ & $\begin{array}{l}\text { Águas Emendadas (DF), } \\
\text { Chapada Diamantina (BA) }\end{array}$ & $\begin{array}{l}\text { Svartman and Almeida 1993, } \\
\text { Pereira and Geise } 2007\end{array}$ \\
\hline & & $44 / 49$ & Granja do Ipê (DF) & Svartman and Almeida 1993 \\
\hline & \multirow{4}{*}{$\begin{array}{l}R \text {. prope } \\
\text { macrurus }\end{array}$} & $44 / 49^{2}$ & Casa Grande (SP) & Svartman and Almeida 1993 \\
\hline & & $44 / 50^{2}$ & Monte Verde (ES) & Zanchin et al. 1992 \\
\hline & & $44 / 50$ & Garrafão (RJ) & Tribe 1996 \\
\hline & & $44 / 51$ & Mocambinho (MG) & Tribe 1996 \\
\hline & R. gardneri & $44 / 50$ & Rio Juruá (AC) & Patton et al. 2000 \\
\hline & R. macconnelli & $44 / 50$ & La Escalera (Venezuela) & Aguilera et al. 1994 \\
\hline
\end{tabular}




\begin{tabular}{|c|c|c|c|c|}
\hline Group & Species & $2 n / F N$ & Locality & Reference \\
\hline & R. cf. mastacalis & $44 / 52$ & Vila Rica (MT), Aripuanã (MT) & \begin{tabular}{|l} 
Silva and \\
Yonenaga-Yassuda 1999
\end{tabular} \\
\hline & R. itoan & $\begin{array}{c}44 / \\
48,49,50\end{array}$ & SP and RJ & Costa et al. 2011 \\
\hline \multirow{4}{*}{$\begin{array}{l}\text { Rhipidomys } \\
\text { mastacalis }\end{array}$} & \multirow{4}{*}{ R. mastacalis } & $44 / 74$ & $\begin{array}{l}\text { Lagoa Santa (MG), Unacau (BA), } \\
\text { Casimiro de Abreu (RJ), } \\
\text { Reserva Biológica Duas Bocas (ES) } \\
\end{array}$ & $\begin{array}{l}\text { Zanchin et al. 1992, } \\
\text { Paresque et al. 1994, } \\
\text { Tribe } 1996\end{array}$ \\
\hline & & $44 / 76$ & Serra da Mesa (GO) & Andrades-Miranda et al. 2002 \\
\hline & & $44 / 80$ & Serra da Mesa (GO) & Andrades-Miranda et al. 2002 \\
\hline & & 344/ high & Serra dos Cavalos (PE) & Zanchin et al. 1992 \\
\hline Hybrid & $\begin{array}{l}\text { Rhipidomys } \\
\text { with high FN } \mathrm{x} \\
\text { Rhipidomys with } \\
\text { low FN }\end{array}$ & $44 / 61$ & M. Chapéu (BA) & $\begin{array}{l}\text { Silva and Yonenaga-Yassuda } \\
1999\end{array}$ \\
\hline \multirow{4}{*}{$\begin{array}{l}\text { Rhipidomys } \\
\text { nitela }\end{array}$} & \multirow{3}{*}{ R. nitela } & $44 / 71$ & San Ignacio, (Venezuela) & Tribe 1996 \\
\hline & & $48 / 67$ & La Trinité (French Guiana) & Volobouev and Catzeflis 2000 \\
\hline & & $48 / 68$ & Surumurú (RR) & Andrades-Miranda et al. 2002 \\
\hline & $R$. prope nitela & $50 / 71,72$ & Manaus (AM) & $\begin{array}{l}\text { Silva and } \\
\text { Yonenaga-Yassuda } 1999 \\
\end{array}$ \\
\hline
\end{tabular}

In this work, we present a new karyotype for Rhipidomys. Our analyses included GTG- and CBG-banding patterns, the silver staining location of the nucleolus organizer regions (Ag-NORs) and fluorescence in situ hybridization (FISH) with a telomere probe.

\section{Material and methods}

We analyzed five specimens (two males and three females) of Rhipidomys sp. captured in 2004 in a dry land region in the margins of the Jequitinhonha river, in Berilo, state of Minas Gerais, Brazil (16 $57^{\prime} 06^{\prime \prime S}, 42^{\circ} 27^{\prime} 56^{\prime \prime W}$; Fig. 1) under the license 129/04-NUFAS/MG from the Instituto Brasileiro para o Meio Ambiente - IBAMA. The skins and skulls were deposited at the Museu de Ciências Naturais da Pontifícia Universidade Católica de Minas Gerais, in Belo Horizonte, Minas Gerais State, Brazil, under the numbers: MCNM 1643, 1644 (two males) and MCNM 1646, 1647, 1648 (three females).

Chromosome preparations were obtained from bone marrow according to the technique described by Ford and Hamerton (1956). GTG- and CBG-banding patterns were obtained following Seabright (1971) and Sumner (1972), respectively, and silver staining of the nucleolus organizer regions (Ag-NORs) was performed according to Howell and Black (1980). FISH with the $\left(\mathrm{T}_{2} \mathrm{AG}_{3}\right)_{\mathrm{n}}$ telomere sequence was performed with the Telomere PNA Kit/FITC (Dako Cytomation) according to the manufacturer's instructions.

The chromosomes were arranged based on the karyotype described for specimens of Rhipidomys sp. by Svartman and Almeida (1993), which were later identified as $R$. macrurus (Tribe 1996). 


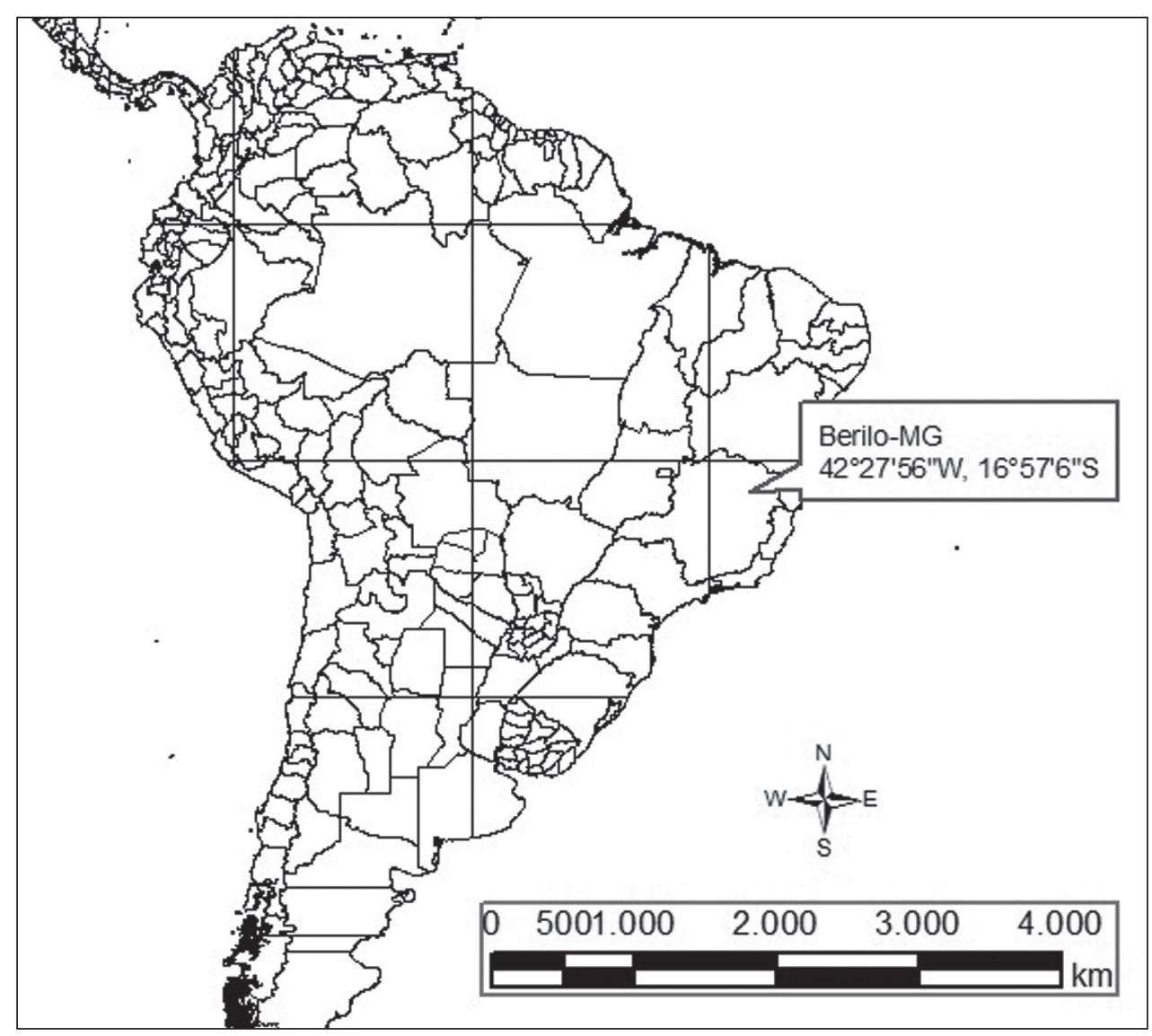

Figure I. Map showing the collection locality of the Rhipidomys sp. analyzed.

\section{Results}

The two males and three females of Rhipidomys sp. analyzed presented a diploid number of $2 \mathrm{n}=44$ chromosomes and a fundamental number $\mathrm{FN}=48$. This karyotype was composed of 21 pairs of autosomes: 18 pairs of acrocentrics with gradual variation in size from large to small (pairs 1 to 9 and 11 to 19), one pair of medium subtelocentrics (pair 10), one pair of small metacentrics (pair 20) and one pair of small submetacentrics (pair 21). The $\mathrm{X}$ chromosome was a large submetacentric with polymorphism in the size of its short arms and the $\mathrm{Y}$ chromosome was a very small acrocentric. Autosomal pairs 1, 10, 19, 20 and 21, the $\mathrm{X}$ and the $\mathrm{Y}$ chromosomes were the only identifiable chromosomes after conventional Giemsa staining (Fig. 2).

After GTG-banding all the autosomes and the sex chromosomes could be identified. The X chromosome presented the two typical mammalian dark GTG-bands in its long arm and no bands were observed on its short arms. The $\mathrm{Y}$ chromosome had an indistinct staining (Fig. 3). 


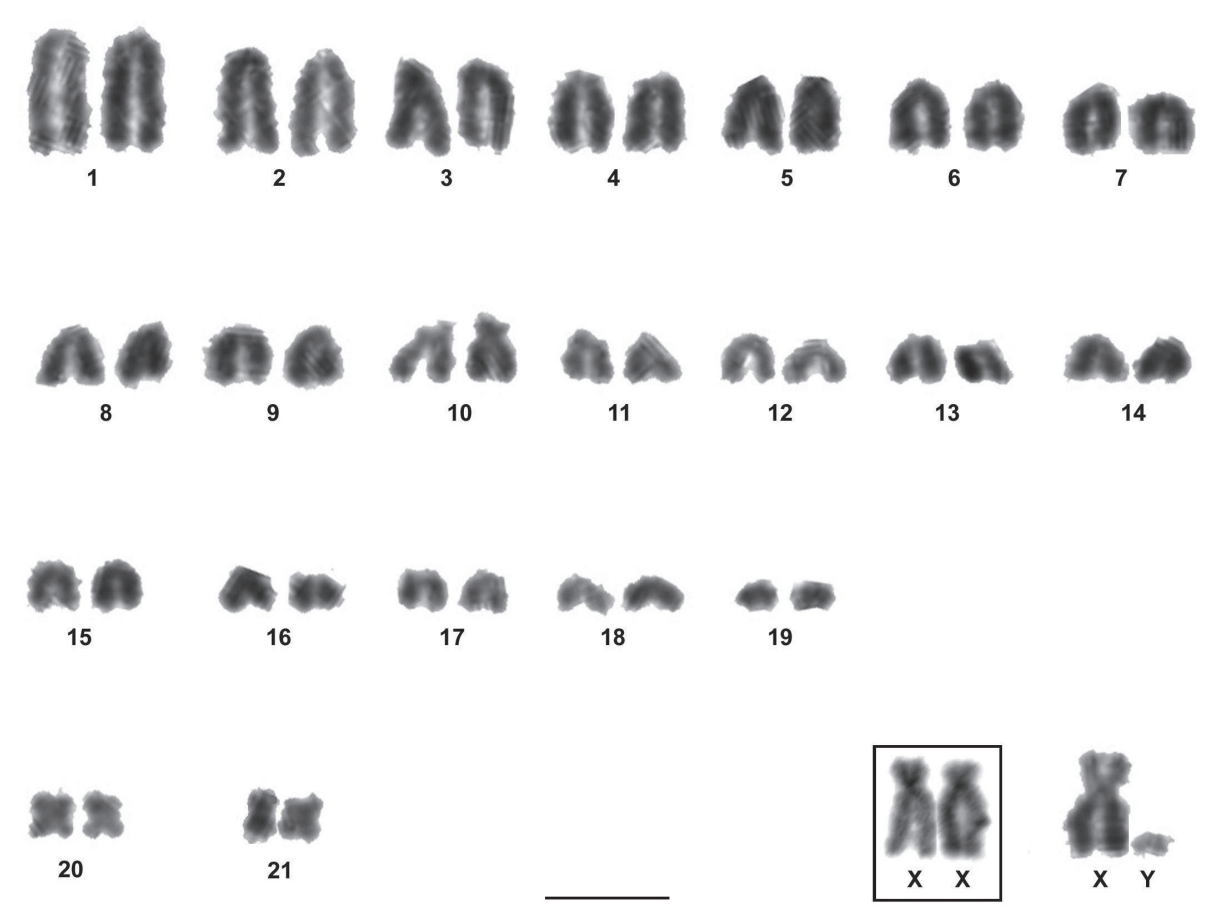

Figure 2. Karyotype of Rhipidomys sp. male $(2 \mathrm{n}=44, \mathrm{FN}=48)$ after conventional Giemsa staining. In the inset, the sex chromosomes of a female. Note the variation in the size of the short arms of the $\mathrm{X}$ chromosomes. Bar $=10 \mu \mathrm{m}$.

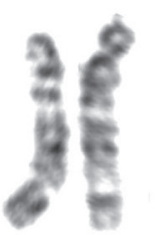

1

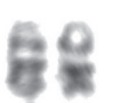

8

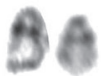

15

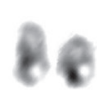

20

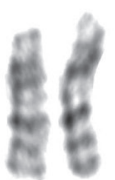

2

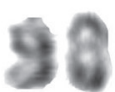

9

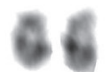

16

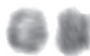

21

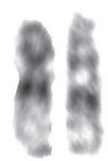

3

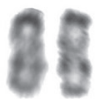

10

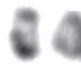

17

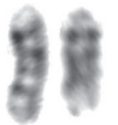

4

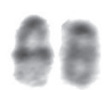

11

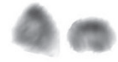

18

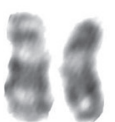

5

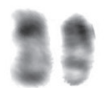

12

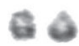

19

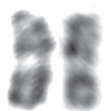

6

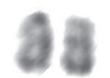

13

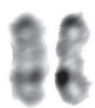

7

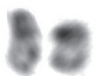

14

Figure 3. GTG-banded karyotype of Rhipidomys sp. male $(2 \mathrm{n}=44, \mathrm{FN}=48)$. In the inset, the sex chromosomes of a female. Bar $=10 \mu \mathrm{m}$. 
CBG-banding revealed the presence of constitutive heterochromatin in the pericentromeric region of most autosomal pairs. The short arm of the $\mathrm{X}$ chromosome was entirely heterochromatic with a stronger stained pericentromeric region and the $\mathrm{Y}$ chromosome displayed a small pericentromeric C-band (Fig. 4).

Silver staining revealed one to five nucleolus organizer regions (Ag-NORs) per cell. The Ag-NORs were located on the short arms of medium/small acrocentric autosomes. From the 151 analyzed cells, the majority (57) showed four Ag-NORs. Associations between NORs were frequent (Table 2, Fig. 5). FISH with the telomere sequences revealed signals only at the telomere regions of all chromosomes (Fig. 6).

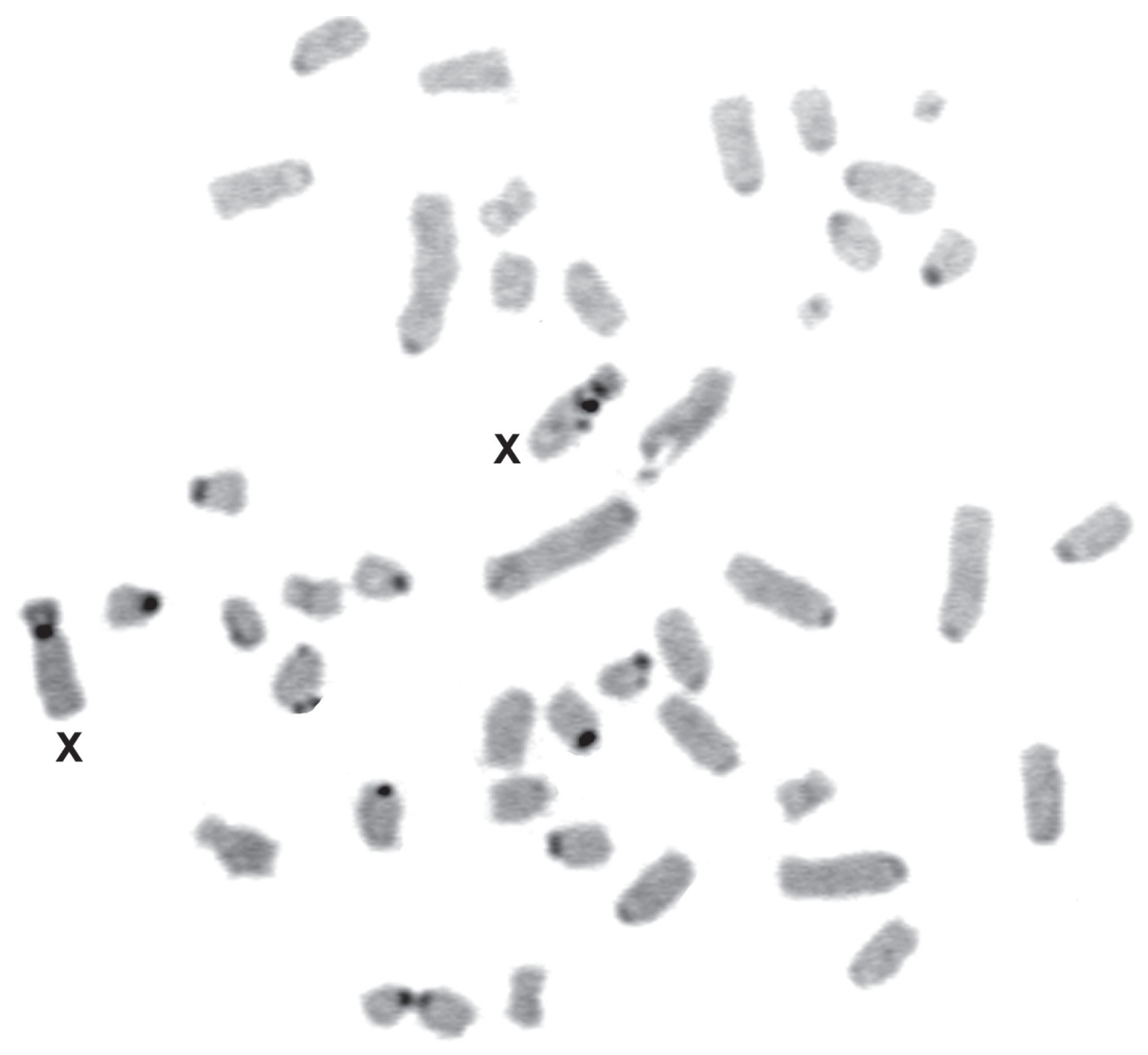

Figure 4. CBG-banding in a metaphase of Rhipidomys sp. female $(2 \mathrm{n}=44, \mathrm{FN}=48) . \mathrm{Bar}=10 \mu \mathrm{m}$. 


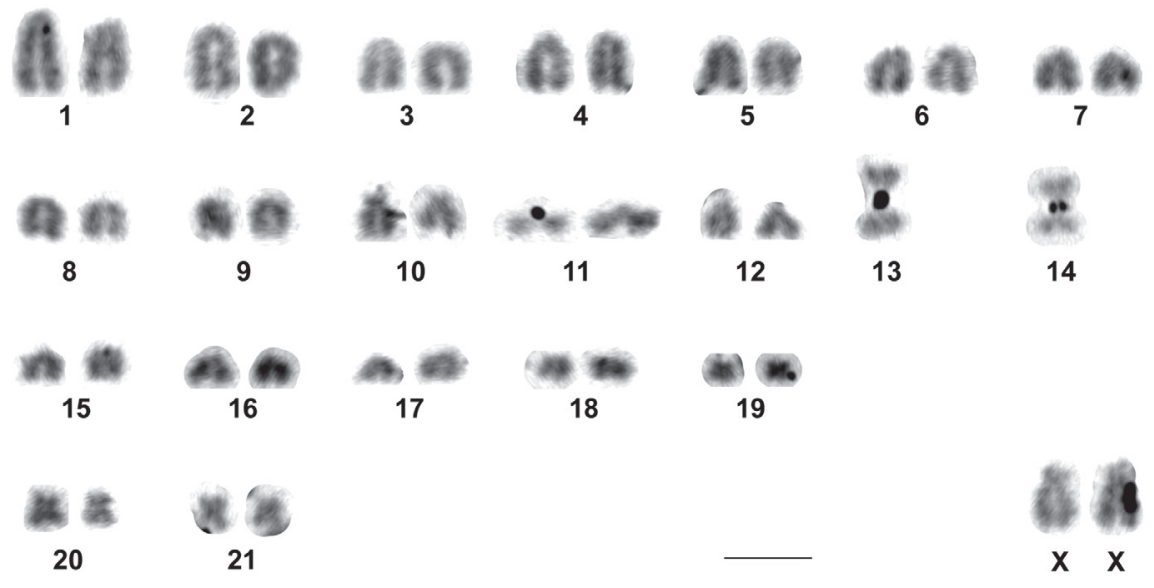

Figure 5. Silver staining of the nucleolus organizer regions (Ag-NORs) in the karyotype of Rhipidomys sp. female $(2 \mathrm{n}=44, \mathrm{FN}=48)$. Bar $=10 \mu \mathrm{m}$.

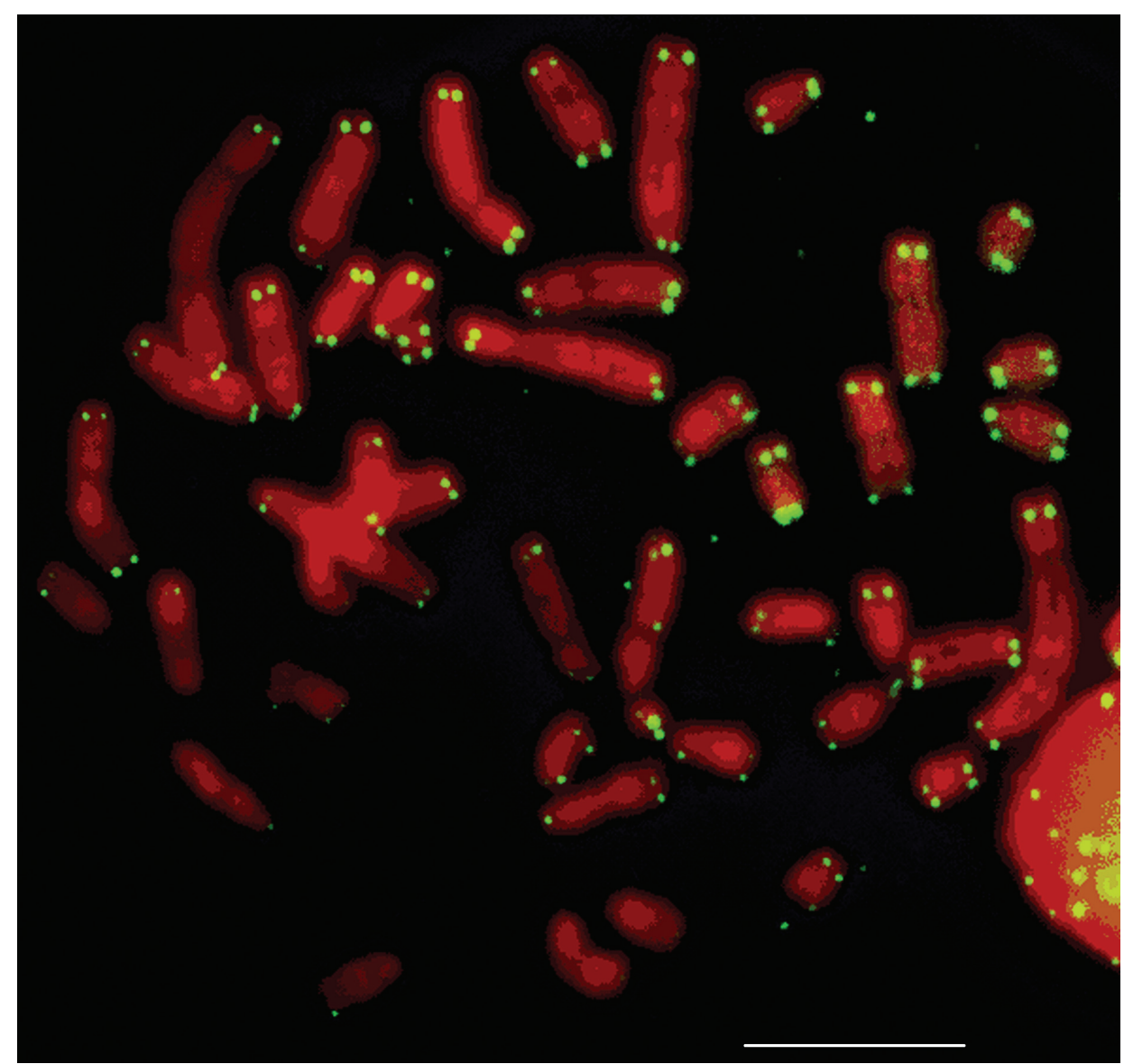

Figure 6. Metaphase of Rhipidomys sp. female $(2 \mathrm{n}=44, \mathrm{FN}=48)$ after FISH with a telomere probe. Bar $=10 \mu \mathrm{m}$. 
Table 2. Number of Ag-NORs per cell in Rhipidomys sp. (2n=44, FN=48).

\begin{tabular}{|c|c|c|c|c|c|c|c|}
\hline & \multicolumn{6}{|c|}{ Number of chromosomes with Ag-NORs } \\
\hline & & 1 & 2 & 3 & 4 & 5 & Total \\
\hline \multirow{6}{*}{ 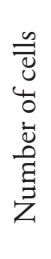 } & MCNM 1643 (Male) & 4 & 5 & 10 & 10 & 1 & 30 \\
\hline & MCNM 1644 (Male) & 2 & 6 & 6 & 13 & 3 & 30 \\
\hline & MCNM 1646 (Female) & 5 & 4 & 10 & 7 & 4 & 30 \\
\hline & MCNM 1647 (Female) & 1 & 3 & 16 & 11 & 0 & 31 \\
\hline & MCNM 1648 (Female) & 1 & 0 & 12 & 16 & 1 & 29 \\
\hline & Total & 13 & 18 & 54 & 57 & 9 & 151 \\
\hline
\end{tabular}

\section{Discussion}

Besides the karyotype of Rhipidomys sp. presented herein, four other species of Rhipidomys with the karyotype formula of $2 \mathrm{n}=44$ and $\mathrm{FN}=48$ have been described: $R$. latimanus Tomes, 1860 from Colombia, for which no karyotype picture has been presented (Gardner and Patton 1976); R. macrurus from the Brazilian states of Goiás and Bahia (Svartman and Almeida 1993, Pereira and Geise 2007), R. leucodactylus collected in the Brazilian states of Rondônia and Goiás (Zanchin et al. 1992, Andrades-Miranda et al. 2002) and in Venezuela (Aguilera et al. 1994), and $R$. itoan from the states of Sáo Paulo and Rio de Janeiro. The animals from Venezuela were originally identified as $R$. sclateri (Aguilera et al. 1994), which was later recognized as a synonym of $R$. leucodactylus (Musser and Carleton 2005).

The karyotype of Rhipidomys sp. studied herein differed from that of $R$. macrurus $(2 \mathrm{n}=44, \mathrm{FN}=48)$ from Goiás (Svartman and Almeida 1993) in the morphologies of pair 10 and of the smallest autosome pair. Pair 10 was subtelocentric in Rhipidomys sp. and acrocentric in $R$. macrurus, whereas the smallest autosome pair was acrocentric in Rhipidomys sp. and metacentric in $R$. macrurus. The $\mathrm{X}$ chromosome was submetacentric in $R$. cariri and acrocentric in $R$. macrurus. The CBG-banding patterns also differed between both species, as only a very small amount of constitutive heterochromatin was detected in R. macrurus (Svartman and Almeida 1993), compared to the pericentromeric C-bands found in most autosomes of Rhipidomys sp. (Fig. 3). Silver staining revealed the presence of 1 to 5 chromosomes with nucleolus organizer regions (Ag-NORs) in Rhipidomys sp. All the NOR-bearing chromosomes were medium acrocentrics similar to the three pairs that presented Ag-NORs in Rhipidomys macrurus (Svartman and Almeida 1993).

GTG-banding patterns have not been described for $R$. leucodactylus, also with $2 \mathrm{n}=44$ and $\mathrm{FN}=48$. From the three biarmed autosomes found in the karyotype of this species, two are comparable in size to the medium acrocentric pair 15 and the third is the smallest autosome pair (Zanchin et al. 1992, Aguilera et al. 1994, AndradesMiranda et al. 2002), whereas in Rhipidomys sp. the biarmed chromosomes correspond in size to pairs 10, 15 and 16. The $\mathrm{X}$ chromosome also differed between both species, being biarmed in $R$. sp. and acrocentric in $R$. leucodactylus. Interestingly, the complement of $R$. leucodactylus seemed identical to that of $R$. macrurus from Goiás (Svartman 
and Almeida 1993), but the absence of GTG-banding patterns of $R$. leucodactylus in the literature hindered further comparisons.

In Rhipidomys itoan with $2 \mathrm{n}=44$ and $\mathrm{FN}=48$ the smallest autosome pair was a submetacentric (Costa et al. 2011), differing from the acrocentric smallest autosome of $R$. sp. presented herein. Morphological variations were observed in two large pairs of $R$. itoan, that could be acrocentric or biarmed, leading to higher fundamental numbers $(\mathrm{FN}=49$ and 50$)$. No such variation was detected in our specimens.

The absence of banding patterns descriptions limited the comparisons of the complement of $R$. sp. described in this work and those of $R$. itoan and $R$. leucodactylus to conventionally stained chromosomes.

The Rhipidomys species already recorded in Minas Gerais were $R$. macrurus, which is probably distributed in the remaining Cerrado fragments of the state, $R$. mastacalis, which was collected in the Atlantic Forest in eastern and southern Minas Gerais, and $R$. tribei, known from only a few sites in the southeastern part of Minas Gerais (Tribe 1996, Bonvicino et al. 2008; Costa et al. 2011).

Rhipidomys mastacalis is characterized by a high fundamental number ( $\mathrm{FN}=74$ through 80) (Zanchin et al. 1992, Paresque et al. 1994, Tribe 1996, Andrades-Miranda et al. 2002) which promptly allows to differentiate its karyotype from that of Rhipidomys sp. ( $\mathrm{FN}=48)$. On the other hand, $R$. macrurus ( $\mathrm{FN}=48-50$; variation due to polymorphism in the morphology of pair 10) (Svartman and Almeida 1993, Pereira and Geise 2007) presented a complement very similar to that of Rhipidomys sp. (FN=48). Nevertheless, as discussed above, the two karyotypes differ in the morphology of the smallest autosome pair (pair 19, acrocentric in Rhipidomys sp., and pair 21, metacentric in $R$. macrurus), and in the amount of constitutive heterochromatin, which can thus be used to differentiate both species. No chromosome data are available for $R$. tribei.

FISH with telomere sequences has been previously performed in specimens of $R$. nitela, $R$. mastacalis and R. leucodactylus (Andrades-Miranda et al. 2002), $R$. prope mastacalis and in animals of two unidentified species (Silva and Yonenaga-Yassuda 1999). As for Rhipidomys sp. presented herein, only terminal signals were observed in the cells of all these specimens. Interstitial signals, which could give clues on chromosome rearrangements, have not been observed in Rhipidomys as yet.

The identification of Rhipidomys specimens from southeastern Brazil at the specieslevel has proven to be specially challenging, with $R$. macrurus and $R$. mastacalis being among the most taxonomically complicated taxa studied (Musser and Carleton 2005; Tribe 1996, Costa et al. 2011).

Chromosome analyses may be useful for the identification of species, especially in complicated taxonomic groups, as is the case of many rodent taxa. As stressed by Tribe (1996), the use of non-morphological characters, as karyotypes, allozymes and DNA sequences, may help in clarifying the phylogenetic relationships and in the taxonomic identification of Rhipidomys species. This prediction has proven right in works like those of Costa et al. (2011) and Rocha et al. (2011), which used molecular data to further the knowledge of the genus, resulting in the description of new species and in the clarification of some phylogenetic relationships. Likewise, karyotypical data, especially 
those including banding patterns, are likely to add new information and to help in clarifying the taxonomy and phylogenetics of this intriguing rodent genus.

With the available data, it seems evident that a larger collection effort including a wider geographical range and complemented by cytogenetic and molecular studies will be needed in order to establish the phylogenetic relationships and phylogeography of Rhipidomys in Brazil. Nevertheless, as exemplified in this work, the use of chromosome data has already proven to be a useful tool in resolving taxonomic issues in this genus.

\section{Acknowledgements}

This work was supported by Fundaçáo de Amparo à Pesquisa do Estado de Minas Gerais, Fapemig (processes CBB APQ-1495-3.12/07, CRA - APQ-00170-09 and APQ-00336-09) and by a grant of the Pró-Reitoria de Pesquisa, UFMG. AHC was a recipient of a graduate fellowship from CAPES, Brazil. The authors are indebted to the Laboratório de Citogenética, Hospital das Clínicas, UFMG, for the use of their laboratory and to Bárbara MA Costa, for the useful discussion of the manuscript.

\section{References}

Aguilera M, Pérez-Zapata A, Martino A, Barros MA, Patton J (1994) Karyosystematics of Aepeomys and Rhipidomys (Rodentia, Cricetidae). Acta Científica Venezoelana 45: 247-248.

Andrades-Miranda J, Oliveira LFB, Lima-Rosa CAV, Sana DA, Nunes AP, Mattevi MS (2002) Genetic studies in representatives of genus Rhipidomys (Rodentia, Sigmodontinae) from Brazil. Acta Theriologica 47: 125-135. doi: 10.1007/BF03192453

Costa BMA, Geise L, Pereira LG, Costa LP (2011) Phylogeography of Rhipidomys (Rodentia, Cricetidae: Sigmodontinae) and description of two new species from southeastern Brazil. Journal of Mammalogy 92: 945-962. doi: 10.1644/10-MAMM-A-249.1

Bonvicino CR, Oliveira JA, D’Andrea OS (2008) Guia dos Roedores do Brasil, com chaves para gêneros baseadas em caracteres externos. Centro Pan-Americano de Febre Aftosa OPAS/OMS, Rio de Janeiro, 122 pp.

Ford CE, Hamerton JL (1956) A colchicine hypotonic citrate squash sequence for mammalian chromosome. Stain Technology 31:247-251.

Gardner AL, Patton JL (1976) Karyotypic variation in Oryzomyini rodents (Cricetinae) with comments on chromosomal evolution in the Neotropical cricetinae complex. Occasional Papers of the Museum of Zoology LA State University 9: 1-48.

Howell WM, Black DA (1980) Controlled silver-staining of nucleolus organizer regions with a protective colloidal developer: a 1-step method. Experientia 36: 1014-1015. doi: 10.1007/ BF01953855

Musser GG, Carleton MD (2005) Family Muridae. In: Wilson DE, Reeder DM (Eds) Mammal Species of the World. A Taxonomic and Geographic Reference. Baltimore, 3rd edition, $1189-1531$. 
Paresque R, Souza WP, Mendes S, Fagundes V (2004) Composição cariotípica da fauna de roedores e marsupiais de duas áreas de Mata Atlântica do Espírito Santo, Brasil. Boletim do Museu de Biologia Mello Leitão 17: 5-33.

Patton JL, da Silva MNF, Malcolm RJ (2000) Mammals of Rio Juruá, Western Amazonian Brazil: Evolutionary and Ecological Diversification. Bulletin American Museum Natural History 244: 1-306. doi: 10.1206/0003-0090(2000)244<0001:MOTRJA>2.0.CO;2

Pereira LG, Geise L (2007) Karyotype composition of some rodents and marsupials from Chapada Diamantina (Bahia, Brasil). Brazilian Journal of Biology 67: 509-518. doi: 10.1590/ S1519-69842007000300016

Rocha RG, Ferreira E, Costa BMA, Martins ICM, Leite YR, Costa LP, Fonseca C (2011) Small mammals of the mid-Araguaia River in Central Brazil, with the description of a new species of climbing rat. Zootaxa 2789: 1-34.

Seabright M (1971) A rapid technique for human chromosomes. Lancet 2: 971-972. doi: 10.1016/S0140-6736(71)90287-X

Silva MJJ, Yonenaga-Yassuda Y (1999) Autosomal and sex chromosomal polymorphisms with multiple rearrangements and a new karyotype in the genus Rhipidomys (Sigmodontinae, Rodentia). Hereditas 131: 211-220. doi: 10.1111/j.1601-5223.1999.00211.x

Smith M, Patton JL (1999) Phylogenetics relationships and the radiation of Sigmodontinae rodents in South America: Evidence from cytochrome b. Journal of Mammalian Evolution 6: 89-128. doi: 10.1023/A:1020668004578

Sumner AT (1972) A simple technique for demonstrating centromeric heterochromatin. Experimental Cell Research 75: 305-306. doi: 10.1016/0014-4827(72)90558-7

Svartman M, Almeida EJC (1993) Pericentric inversion and X chromosome polymorphism in Rhipidomys sp. (Cricetidae, Rodentia) from Brazil. Caryologia 46: 219-225.

Tribe CJ (1996) The Neotropical rodent genus Rhipidomys (Cricetidae, Sigmodontinae) - a taxonomic revision. PhD Dissertation, University College, London, 316 pp.

Volobouev VT, Catzeflis FM (2000) Chromosome banding analysis (G-, R- and C-bands) of Rhipidomys nitela and a review of the cytogenetics of Rhipidomys (Rodentia, Sigmodontinae). Mammalia 64: 353-360. doi: 10.1515/mamm.2000.64.3.353

Zanchin NIT, Langguth A, Mattevi MS (1992) Karyotypes of Brazilian species of Rhipidomys (Rodentia, Cricetidae). Journal of Mammalogy 73: 120-122. doi: 10.2307/1381872 
